\title{
Karakteristik ekologi, kondisi kesehatan dan tingkat kerawanan degradasi mangrove saat penginisiasian KKPD Rupat Utara 2018
}

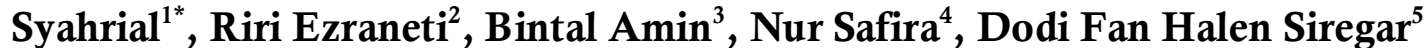 \\ ${ }^{1,2}$ Dosen Program Studi Ilmu Kelautan, Fakultas Pertanian, Universitas Malikussaleh, Aceh, Indonesia \\ ${ }^{3}$ Jurusan Ilmu Kelautan, Fakultas Perikanan dan Kelautan, Universitas Riau, Riau, Indonesia \\ 4,5 Mahasiswa Program Studi Ilmu Kelautan, Fakultas Pertanian, Universitas Malikussaleh, Aceh \\ *Koresponden E-mail: syahrial.marine@unimal.ac.id
}

(Diterima 24 Agustus 2020| Disetujui 02 Januari 2021 |Diterbitkan 30 Januari 2021)

\begin{abstract}
The study of ecological characteristics, health conditions and the level of vulnerability of mangrove degradation when initiating North Rupat as a Regional Aquatic Conservation Area (KKPD) was conducted in July 2018 with the aim of future baseline data and comparison. Data collection on the condition of mangrove vegetation is carried out by making line transects and plots drawn from the reference point (outermost mangrove stands) in a direction perpendicular to the coastline to the mainland. The results of the study showed that 12 identified species. The diversity index and dominance are relatively low $\left(H^{\prime} \leq 2.0\right.$ and $\left.0<C \leq 0.5\right)$, while the uniformity is classified as stable $(0.75<$ $E \leq 1)$. For the density of mangroves the highest category of trees is at Station 4 (2525 ind/ha \pm 638.15$)$, while the density of saplings and seedlings at Station 1 (2800 ind/ha \pm 873.48 and 50000 ind/ha \pm 17638.34 ), where Xylocarpus granatum is the dominant species in the tree and seedling category (Importance Value Index/IVI 191.74\% and $240.80 \%$ ), while Avicennia alba was for the saplings category (IVI 216.01\%). In the main land part of the North Rupat KKPD area, the mangroves' health condition was increasingly threatened by destruction compared to the small islands around it. However, overall the level of vulnerability of mangrove degradation in the initiating area of North Rupat KKPD is still relatively low.
\end{abstract}

\section{Keywords: ecological characteristics, health conditions, degradation vulnerability, mangroves, KKPD, North Rupat}

Hutan mangrove merupakan ekosistem pesisir tropis dan subtropis (Polania et al., 2015; Alongi, 2018; Gaut, 2018) yang tumbuh di 120 negara (Kuenzer et al., 2011) pada lintang yang rendah (Alongi, 2018), sensitif terhadap pasang surut ait laut dan berada di sepanjang pantai yang terlindungi (Woodroffe \& Grindrod, 1991), memiliki akses yang mudah (Onrizal, 2010) sebagai daerah pertemuan antara darat dan laut (Vane et al., 2009) serta menjadi salah satu pusat isu lingkungan dunia (Onrizal, 2010). Asal kata "mangrove" tidak diketahui secara jelas dan terdapat berbagai pendapat mengenai asal-usul katanya. Macnae (1968) menyebutkan kata mangrove merupakan perpaduan antara bahasa Portugis "mangue" dan Inggris "grove". Sementara menurut Mastaller (1997) kata mangrove berasal dari bahasa Melayu kuno yaitu "mangi-mangi" yang digunakan untuk menjelaskan marga Avicennia dan hingga saat ini masih digunakan di Indonesia bagian Timur. Umumnya kata mangrove merujuk pada jenis pohon (Brown, 2007), semak belukar, tipe hutan (Brown, 2007) ataupun komunitas (Holguin et al., 2001), dimana kawasannya meluas di sepanjang sungai dan anak-anak sungai yang berairan payau (Brown, 2007) serta dipengaruhi oleh salinitas, cahaya, suhu, ketidakstabilan tanah maupun musim yang berganti (Feller et al., 2010).

Salah satu manfaat mangrove adalah dapat mendukung keanekaragaman hayati global (Valenca \& Santos, 2012) serta memainkan peran penting sebagai produsen utama di daerah pesisir (Bayen, 2012; Wang et al., 2013). Selain itu, mangrove juga berkontribusi terhadap kesejahteraan manusia (Kusmana, 2011;
Ishak \& Saputra, 2015; Polania et al., 2015), baik itu sebagai mata pencaharian, pendapatan, keamanan pangan, layanan kesehatan, pengurangan kemiskinan dan sosial yang berkelanjutan (UNEP, 2014). Pada tahun 2000, total luas mangrove global mencapai $137.760 \mathrm{~km}^{2}$ (Giri et al., 2011) dengan tingkat degradasi pada periode 1990 - 2000 mencapai $1 \%$ per tahun (dua kali lipat dari hutan hujan terestrial) (Mayaux et al., 2005) dan sejak tahun 2000 menjadi $0.39 \%$ per tahun (Hamilton \& Casey, 2016). Aktivitas budidaya (akuakultur) merupakan penyebab/penyumbang deforestasi terbesar mangrove (Hamilton, 2013; UNEP, 2014; Thomas et al., 2017), kemudian mangrove juga diancam oleh kegiatan reklamasi pantai (Jin-Eong, 1995), eksploitasi kayu yang berlebihan (UNEP, 2014; Ilman et al., 2016; Thomas et al., 2017), pencemaran (UNEP, 2014; Thomas et al., 2017), pertanian (Richards \& Friess, 2016); permukiman penduduk (Ishak \& Saputra, 2015), urbanisasi maupun industrialisasi (Bosire et al., 2008), sehingga tingginya produktivitas mangrove dibandingkan lahan basah yang lain (Sandilyan \& Kathiresan, 2012; Chakraborty, 2013; Hartati \& Harudu, 2016; Osland et al., 2016) tidak menjamin kelestariannya untuk tetap terjaga.

Terlepas dari hal di atas, Kawasan Konservasi Perairan Daerah (KKPD) merupakan salah satu bentuk pengelolaan konservasi perairan di Indonesia yang bertujuan untuk melindungi habitat, struktur, fungsi dan intergritas ekosistem, keragaman, kekayaan maupun kepadatan atau kelimpahan spesies laut (Angulo \& Hatcher, 2010; Salm et al., 2010). Selain itu, pembentukan KKPD juga bertujuan untuk memanfaatkan sumberdaya laut secara berkelanjutan, 
mengelola sumberdaya laut secara efektif, menjamin kelestarian ekosistem laut untuk menopang kehidupan masyarakat yang bergantung pada sumberdaya laut serta mengatur aktivitas masyarakat dalam kawasan pengelolaan (Wiryawan \& Dermawan, 2006).

Rupat Utara merupakan salah satu kecamatan di Kabupaten Bengkalis yang berada di Pulau Rupat. Di sebelah Timur, Utara dan Baratnya berbatasan dengan Selat Malaka, sedangkan di sebelah Selatan berbatasan dengan Kecamatan Rupat (BPS Bengkalis, 2016). Luas wilayah Rupat Utara mencapai 628.50 $\mathrm{km}^{2}$ dengan desa terluasnya adalah Desa Titi Akar $\left(185 \mathrm{~km}^{2}\right)$ dan desa terkecilnya adalah Desa Kadur (52 $\mathrm{km}^{2}$ ) (BPS Bengkalis, 2017). Rupat Utara mempunyai potensi yang sangat besar dibidang perikanan, terutama perikanan tangkap. Hal ini didukung oleh adanya 6 sungai, 7 pulau-pulau kecil dan 7 desa pesisir yang tinggi geografisnya mencapai $5 \mathrm{~m}$ di atas permukaan laut serta berhadapan langsung dengan perairan internasional Selat Melaka. Untuk merekomendasikan perairan Rupat Utara sebagai KKPD, maka haruslah dilihat kondisi ekosistemnya. Salah satu ekosistem yang dilihat adalah hutan mangrove, sehingga sangat diperlukan adanya suatu kajian tentang karakteristik ekologi, kondisi kesehatan dan tingkat kerawanan degradasi hutan mangrovenya. Hal ini bertujuan untuk mengetahui biodiversitas, tingkat keanekaragaman, dominansi, keseragaman, kerapatan, INP dan kerawanan degradasi hutan mangrovenya, sehingga dapat dijadikan sebagai data baseline dan pembanding di masa yang akan datang.

\section{BAHAN DAN METODE}

\section{Waktu dan Tempat Penelitian}

Kajian dilakukan pada bulan Juli 2018 dengan lokasi penelitian terfokus pada wilayah Desa Titi Akar, Suka Damai, Tanjung Medang dan Pulau Babi, kemudian sebanyak enam titik lokasi telah ditentukan sebagai stasiun pengamatan dan pengambilan sampelnya (Tabel 1 \& Gambar 1). Alat yang digunakan selama penelitian adalah rol meter, buku identifikasi mangrove Noor et al., (2006), data sheet, kamera dan GPS (Global Positioning System). Selanjutnya, data kondisi vegetasi mangrove dikumpulkan dengan membuat transek garis dan plot (petak-petak contoh) yang berukuran 10 x $10 \mathrm{~m}$ (kategori pohon), 5 x $5 \mathrm{~m}$ (kategori anakan) dan 1 x 1 m (kategori semai) (Bengen, 2004), dimana lingkar batang mangrovenya diukur berdasarkan MNLH (2004).

Tabel 1. Koordinat penelitian mangrove di kawasan penginisiasian KKPD Rupat Utara

\begin{tabular}{lccc}
\hline \multirow{2}{*}{ Lokasi } & \multirow{2}{*}{ St } & \multicolumn{2}{c}{ Koordinat } \\
\cline { 3 - 4 } & & $\mathbf{N}$ & $\mathbf{E}$ \\
\hline Titi Akar 1 & 1 & $02^{\circ} 02^{\prime} 08.39^{\prime \prime}$ & $101^{\circ} 34^{\prime} 37.52^{\prime \prime}$ \\
Titi Akar 2 & 2 & $02^{\circ} 02^{\prime} 39.88^{\prime \prime}$ & $101^{\circ} 33^{\prime} 45.17^{\prime \prime}$ \\
Suka Damai & 3 & $02^{\circ} 03^{\prime} 20.46^{\prime \prime}$ & $101^{\circ} 34^{\prime} 05.20^{\prime \prime}$ \\
Pulau Babi & 4 & $02^{\circ} 05^{\prime} 36.45^{\prime \prime}$ & $101^{\circ} 33^{\prime} 13.16^{\prime \prime}$ \\
Tjg. Medang 1 & 5 & $02^{\circ} 06^{\prime} 15.70^{\prime \prime}$ & $101^{\circ} 37^{\prime} 18.70^{\prime \prime}$ \\
Tjg. Medang 2 & 6 & $02^{\circ} 06^{\prime} 83.00^{\prime \prime}$ & $101^{\circ} 38^{\prime} 29.70^{\prime \prime}$ \\
\hline
\end{tabular}
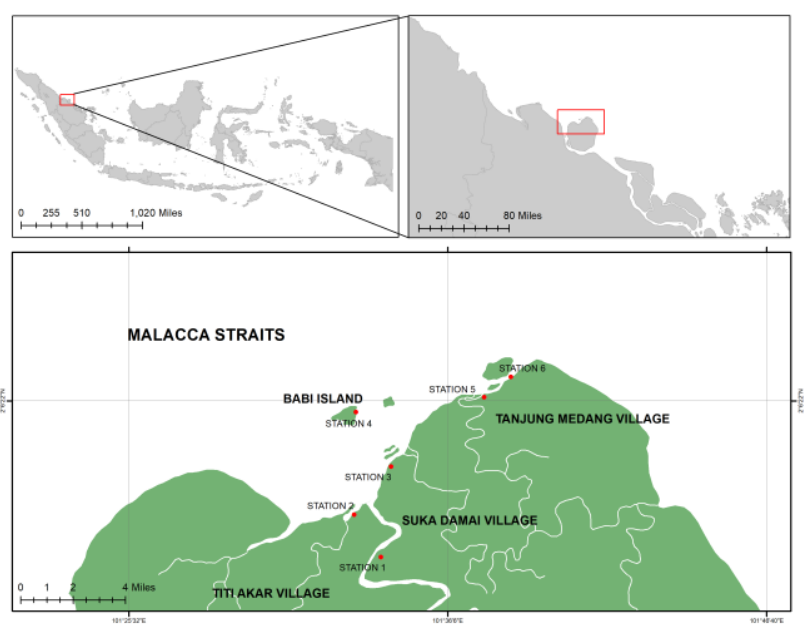

Gambar 1. Lokasi penelitian

Keanekaragaman mangrove di kawasan penginisiasian KKPD Rupat Utara dianalisis menggunakan indeks keanekaragaman ShannonWeaver, dominansi mangrove dianalisis menurut indeks dominansi Simpson dan keseragaman mangrove dianalisis menurut indeks keseragaman Shannon-Weaver, dimana kriteria indeks keanekaragaman Shannon-Weaver adalah $\mathrm{H}^{\prime} \leq 2.0$ (keanekaragaman rendah), $2.0<\mathrm{H}^{\prime} \leq 3.0$ (keanekaragaman sedang) dan $\mathrm{H}^{\prime} \geq 3.0$ 
(keanekaragaman tinggi) (Setyobudiandy et al., 2009), sedangkan kriteria indeks dominansi Simpson adalah 0 $<\mathrm{C} \leq 0.5$ (dominansi rendah), $0.5<\mathrm{C} \leq 0.75$ (dominansi sedang) dan $0.75<\mathrm{C} \leq 1$ (dominansi tinggi) (Setyobudiandy et al., 2009). Selanjutnya kriteria indeks keseragaman Shannon-Weaver adalah 0 $<\mathrm{E} \leq 0.5$ (komunitas dalam keadaan tertekan), $0.5<\mathrm{E}$ $\leq 0.75$ (komunitas dalam keadaan labil) dan $0.75<\mathrm{E} \leq$ 1 (komunitas dalam keadaan stabil) (Setyobudiandy et al., 2009).

Selain itu, kerapatan mangrove di kawasan penginisiasian KKPD Rupat Utara dihitung berdasarkan ratio dari jumlah masing-masing tingkatan (pohon/anakan/semai) di setiap plot dan dibagi satuan luas plotnya, sedangkan Indeks Nilai Penting (INP) dihitung berdasarkan penjumlahan hasil kerapatan relatif, frekuensi relatif dan dominansi relatif. Selanjutnya untuk menilai tingkat kesehatan mangrove di kawasan penginisiasian KKPD Rupat Utara mengacu pada MNLH (2004), dimana kerapatan $\geq$ $1500 \mathrm{ind} / \mathrm{ha}$ tergolong baik (sangat padat), 1000 - 1500 ind/ha tergolong baik (sedang) dan < 1000 ind/ha tergolong rusak (jarang). Sementara untuk menilai tingkat kerawanan degradasi mangrove di kawasan penginisiasian KKPD Rupat Utara mengacu pada Kaunang \& Kimbal (2009) dengan kriterianya disajikan pada Tabel 2 .

Tabel 2. Penentuan tingkat kerentanan degradasi ekosistem hutan mangrove KKPD Rupat Utara (Kaunang \& Kimbal, 2009)

\begin{tabular}{lccc}
\hline \multirow{2}{*}{$\begin{array}{l}\text { Kerapatan } \\
\text { Mangrove }\end{array}$} & \multicolumn{3}{c}{ Tingkat Kerentanan Degradasi (ind/ha) } \\
\cline { 2 - 4 } & $\begin{array}{c}\text { Kerentanan } \\
\text { Rendah }\end{array}$ & $\begin{array}{c}\text { Kerentanan } \\
\text { Sedang }\end{array}$ & $\begin{array}{c}\text { Kerentanan } \\
\text { Tinggi }\end{array}$ \\
\hline Pohon & $>1500$ & $750-1500$ & $<750$ \\
Anakan & $>2500$ & $750-2500$ & $<750$ \\
Semai & $>5000$ & $1000-5000$ & $<1000$ \\
\hline
\end{tabular}

Tabel 3. Penyebaran spesies mangrove sejati di kawasan penginisiasian KKPD Rupat Utara

\begin{tabular}{|c|c|c|c|c|c|c|c|}
\hline \multirow{2}{*}{ No } & \multirow{2}{*}{ Spesies } & \multicolumn{6}{|c|}{ Stasiun } \\
\hline & & 1 & 2 & 3 & 4 & 5 & 6 \\
\hline 1 & X. granatum & & + & & + & + & \\
\hline 2 & R. apiculata & & + & & + & + & \\
\hline 3 & R. mucronata & & & & + & & \\
\hline 4 & B. gymnorrhiza & & + & & + & & \\
\hline 5 & B. sexangula & & & & + & & \\
\hline 6 & C. tagal & & + & & & + & \\
\hline 7 & S. hydrophyllaceae & & + & & & + & \\
\hline 8 & S. caseolaris & + & & + & & & + \\
\hline 9 & S. alba & + & & + & & & + \\
\hline 10 & A. alba & + & & + & & & + \\
\hline 11 & A. lanata & & & & + & & + \\
\hline 12 & L. littorea & & & & & + & \\
\hline
\end{tabular}

\section{HASIL}

Keanekaragaman hayati mangrove di kawasan penginisiasian KKPD Rupat Utara teridentifikasi sebanyak 12 spesies (Tabel 3). Untuk Desa Titi Akar ditemukan spesies Xylocarpus granatum, Rhizophora apiculata, Bruguiera gymnorrhiza, Ceriops tagal, Scyphiphora hydrophyllaceae, Sonneratia caseolaris, S. alba dan Avicennia alba, sedangkan di Desa Suka Damai ditemukan spesies $S$. caseolaris, $S$. alba dan $A$. alba. Selanjutnya di Desa Tanjung Medang ditemukan spesies $S$. hydrophyllaceae, $R$. apiculata, X. granatum, $C$. tagal, Lumnitzera littorea, $S$. caseolaris, $S$. alba, A. alba dan $A$. lanata, sedangkan di Pulau Babi ditemukan $B$. sexangula, $X$. granatum, $R$. mucronata, $R$. apiculata dan $A$. lanata. Pada Stasiun 2, 4 dan 5 ditemukan dua spesies yang sama yaitu $X$. granatum dan $R$. apiculata, sedangkan $C$. tagal dan $S$. hydrophyllaceae ditemukan sama pada Stasiun 2 dan 5. Untuk B. gymnorrhiza, juga ditemukan sama pada Stasiun 2 dan 4, sedangkan $S$. caseolaris, $S$. alba dan $A$. alba ditemukan sama pada Stasiun 1, 3 dan 6, kemudian spesies $A$. lanata ditemukan sama pada Stasiun 4 dan 6 , sedangkan $R$. mucronata maupun $B$. sexangula hanya ditemukan di Stasiun 4. Begitu juga dengan $L$. racemosa yang hanya ditemukan di Stasiun 5.

Nilai indeks keanekaragaman ( $\left.\mathrm{H}^{\prime}\right)$ mangrove di kawasan penginisiasian KKPD Rupat Utara secara keseluruhannya berkategori rendah $\left(\mathrm{H}^{\prime} \leq 2.0\right)$, dimana nilai terendahnya ditemukan pada Stasiun 2 (1.34) dan tertingginya ditemukan pada Stasiun 1 (1.72) (Tabel 4). Selain itu, Tabel 4 juga memperlihatkan bahwa nilai indeks dominansi (C) mangrove di kawasan penginisiasian KKPD Rupat Utara juga berkategori rendah $(0<\mathrm{C} \leq 0.5)$ dengan nilai terendahnya pada Stasiun 5 (0.36) dan tertingginya pada Stasiun 2 (0.43), kemudian nilai indeks keseragaman (E) mangrovenya berkategori stabil $(0.75<\mathrm{E} \leq 1)$ dengan nilai terendahnya pada Stasiun 4 (0.64) dan tertingginya pada Stasiun 3 (0.91).

Tabel 4. Indeks ekologi mangrove di kawasan penginisiasian KKPD Rupat Utara

\begin{tabular}{ccccccc}
\hline \multirow{2}{*}{ St } & \multicolumn{2}{c}{ H' $^{\prime}$} & \multicolumn{2}{c}{ C } & \multicolumn{2}{c}{ E } \\
\cline { 2 - 7 } & Nilai & Kat & Nilai & Kat & Nilai & Kat \\
\hline 1 & 1.72 & Rdh & 0.40 & Rdh & 0.74 & Lab \\
2 & 1.34 & Rdh & 0.43 & Rdh & 0.85 & Sta \\
3 & 1.44 & Rdh & 0.40 & Rdh & 0.91 & Sta \\
4 & 1.65 & Rdh & 0.41 & Rdh & 0.64 & Lab \\
5 & 1.71 & Rdh & 0.36 & Rdh & 0.73 & Lab \\
6 & 1.64 & Rdh & 0.38 & Rdh & 0.82 & Sta \\
Rat & $\mathbf{1 . 5 8}$ & Rdh & $\mathbf{0 . 4 0}$ & Rdh & $\mathbf{0 . 7 8}$ & Sta \\
\hline
\end{tabular}

St = Stasiun; Kat = Kategori; Rdh = Rendah; Lab = Labil; Sta $=$ Stabil; Rat $=$ Rata-Rata 
Analisis kerapatan mangrove di kawasan penginisiasian KKPD Rupat Utara memperlihatkan bahwa kategori pohon tertingginya berada di Stasiun 4 (2525 ind/ha \pm 638.15$)$, sedangkan kerapatan anakan dan semai tertingginya di Stasiun 1 (2800 ind/ha \pm 873.48 dan $50000 \mathrm{ind} / \mathrm{ha} \pm 17638.34$ ) (Tabel 5), sehingga hal ini mengindikasikan bahwa kondisi penutupan mangrove kategori pohon lebih baik di Stasiun 4 dan kondisi penutupan mangrove kategori anakan maupun semai di Stasiun 1 dengan kerapatan kategori pohon berkisar antara 775-2525 ind/ha, kategori anakan 150 - 2800 ind/ha dan kategori semai 6667-50000 ind/ha. Selain itu, analisis INP mangrove di kawasan penginisiasian KKPD Rupat Utara menunjukkan bahwa nilai INP ketegori pohon tertingginya adalah spesies $X$. granatum (191.74\%) dan terendahnya $A$. lanata $(06.25 \%)$, kemudian nilai INP kategori anakan tertingginya adalah $A$. alba (216.01\%) dan terendahnya $B$. gymnorrhiza (12.33\%), sedangkan nilai INP kategori semai tertinggi dan terendahnya adalah $X$. granatum (240.80\% dan 29.06\%) (Tabel 5).

Kondisi kesehatan mangrove di kawasan penginisiasian KKPD Rupat Utara menunjukkan bahwa untuk kategori pohon, Stasiun 1, 2, 4 dan 5 tergolong baik (sangat padat), Stasiun 3 tergolong rusak (jarang) dan Stasiun 6 tergolong baik (sedang), kemudian untuk kategori anakan, Stasiun 1 tergolong baik (sangat padat), Stasiun 2, 4 dan 6 tergolong baik (sedang), dan Stasiun 3 maupun 5 tergolong rusak (jarang), sedangkan untuk kategori semai, kondisi kesehatan mangrove di semua stasiun pengamatannya tergolong baik (sangat padat) (Tabel 6).

Tabel 5. Kondisi kerapatan dan Indeks Nilai Penting (INP) mangrove kawasan penginisiasian KKPD Rupat Utara

\begin{tabular}{|c|c|c|c|c|c|c|c|c|c|}
\hline \multirow{3}{*}{ St } & \multirow{2}{*}{\multicolumn{3}{|c|}{ Kerapatan (ind/ha) }} & \multicolumn{6}{|c|}{ INP (\%) } \\
\hline & & & & & Minim & & & Iaksimu & \\
\hline & $\mathbf{P}$ & A & $\mathbf{S}$ & $\mathbf{P}$ & A & S & $\mathbf{P}$ & A & $\mathbf{S}$ \\
\hline \multirow[b]{2}{*}{1} & 1833 & 2800 & 50000 & $\mathrm{CT}$ & $\mathrm{CT}$ & $\mathrm{XG}$ & RA & $\mathrm{XG}$ & $\mathrm{CT}$ \\
\hline & \pm 496.10 & \pm 873.48 & \pm 17638.34 & 13.21 & 19.50 & 31.79 & 53.49 & 208.46 & 191.51 \\
\hline \multirow{2}{*}{2} & 1750 & 1400 & 10000 & SA & SC & $\mathrm{AA}$ & SC & $\mathrm{AA}$ & SC \\
\hline & \pm 401.04 & \pm 707.11 & \pm 0.00 & 46.91 & 83.99 & 118.51 & 170.90 & 216.01 & 181.49 \\
\hline \multirow{2}{*}{3} & 775 & 150 & 13750 & $\mathrm{SC}$ & $\mathrm{SC}$ & SA & $\mathrm{AA}$ & AA & SC \\
\hline & \pm 134.82 & \pm 35.36 & \pm 3145.76 & 64.66 & 88.79 & 39.18 & 160.82 & 211.21 & 159.45 \\
\hline \multirow{2}{*}{4} & 2525 & 1250 & 15000 & $\mathrm{AL}$ & BG & XG & XG & BS & $\mathrm{RM}$ \\
\hline & \pm 638.15 & \pm 309.23 & \pm 3061.86 & 06.25 & 12.33 & 29.06 & 191.74 & 185.33 & 139.31 \\
\hline \multirow{2}{*}{5} & 1544 & 844 & 20000 & $\mathrm{CT}$ & $X G$ & $\mathrm{RA}$ & $\mathrm{SH}$ & $\mathrm{SH}$ & XG \\
\hline & \pm 1013.52 & \pm 168.26 & \pm 12570.79 & 10.58 & 22.40 & 59.20 & 140.97 & 119.47 & 240.80 \\
\hline \multirow{2}{*}{6} & 1400 & 1067 & 6667 & $\mathrm{AL}$ & $\mathrm{AL}$ & $\mathrm{AA}$ & SC & SC & SC \\
\hline & \pm 332.78 & \pm 203.67 & \pm 0.00 & 17.74 & 37.96 & 120.83 & 164.07 & 100.51 & 179.17 \\
\hline
\end{tabular}

St = Stasiun; P = Pohon; $\mathrm{A}=$ Anakan; $\mathrm{S}=$ Semai; $\mathrm{CT}=$ Ceriops tagal; $\mathrm{XG}=$ Xylocarpus granatum; RA = Rhizophora apiculata; SA = Sonneratia alba SC = Sonneratia caseolaris; AA = Avicennia alba $;$ AL = Avicennia lanata; $\mathrm{BG}=$ Bruguiera gymnorrhiza; $\mathrm{BS}=$ Bruguiera sexangula; $\mathrm{RM}=$ Rhizophora mucronata; $\mathrm{SH}=$ Scyphiphora hydrophyllaceae

Tabel 6. Kondisi kesehatan mangrove di kawasan penginisiasian KKPD Rupat Utara

\begin{tabular}{|c|c|c|c|c|c|c|}
\hline Stasiun & $\begin{array}{c}\text { Kerapatan } \\
\text { Pohon (ind/ha) }\end{array}$ & $\begin{array}{c}\text { Kondisi } \\
\text { Kesehatan }\end{array}$ & $\begin{array}{c}\text { Kerapatan } \\
\text { Anakan } \\
\text { (ind/ha) }\end{array}$ & $\begin{array}{c}\text { Kondisi } \\
\text { Kesehatan }\end{array}$ & $\begin{array}{c}\text { Kerapatan } \\
\text { Semai } \\
\text { (ind/ha) }\end{array}$ & $\begin{array}{l}\text { Kondisi } \\
\text { Kesehatan }\end{array}$ \\
\hline 1 & $\begin{array}{c}1833 \\
\pm 496.10\end{array}$ & $\mathrm{a}$ & $\begin{array}{c}2800 \\
\pm 873.48\end{array}$ & $\mathrm{a}$ & $\begin{array}{c}50000 \\
\pm 17638.34\end{array}$ & $\mathrm{a}$ \\
\hline 2 & $\begin{array}{c}1750 \\
\pm 401.04\end{array}$ & $\mathrm{a}$ & $\begin{array}{c}1400 \\
\pm 707.11\end{array}$ & $\mathrm{~b}$ & $\begin{array}{l}10000 \\
\pm 0.00\end{array}$ & $\mathrm{a}$ \\
\hline 3 & $\begin{array}{c}775 \\
+134.82\end{array}$ & c & $\begin{array}{c}150 \\
+35.36\end{array}$ & c & $\begin{array}{l}13750 \\
\pm 3145.76\end{array}$ & $\mathrm{a}$ \\
\hline 4 & $\begin{array}{c}2525 \\
+638.15\end{array}$ & $\mathrm{a}$ & $\begin{array}{c}1250 \\
\pm 309.23\end{array}$ & $b$ & $\begin{array}{c}15000 \\
\pm 3061.86\end{array}$ & $\mathrm{a}$ \\
\hline 5 & $\begin{array}{c}1544 \\
\pm 1013.52\end{array}$ & $\mathrm{a}$ & $\begin{array}{c}844 \\
\pm 168.26\end{array}$ & C & $\begin{array}{c}20000 \\
\pm 12570.79\end{array}$ & $\mathrm{a}$ \\
\hline 6 & $\begin{array}{c}1400 \\
\pm 332.78\end{array}$ & $b$ & $\begin{array}{c}1067 \\
\pm 203.67\end{array}$ & $b$ & $\begin{array}{c}6667 \\
\pm 0.00\end{array}$ & $\mathrm{a}$ \\
\hline
\end{tabular}

$\mathrm{a}=$ Bagus (sangat rapat); $\mathrm{b}=$ Bagus (sedang); $\mathrm{c}=$ Rusak (jarang)

Analisis terhadap penilaian tingkat kerawanan degradasi mangrove di kawasan penginisiasian KKPD Rupat Utara menunjukkan bahwa mangrove kategori pohon pada Stasiun 1, 2, 4 dan 5 tergolong rawan rendah, sedangkan Stasiun 3 dan 6 tergolong rawan sedang, kemudian mangrove kategori anakan pada 
Stasiun 1 tergolong rawan rendah, Stasiun 2, 4, 5 dan 6 tergolong rawan sedang, sedangkan Stasiun 3 tergolong rawan tinggi (Tabel 7).

\section{PEMBAHASAN}

Hutan mangrove di kawasan penginisiasian KKPD Rupat Utara pada umumnya tumbuh di substrat berlumpur, baik itu di sekitar muara sungai maupun di pinggiran laut, dimana spesies yang memiliki penyebaran luas adalah $X$. granatum, $R$. apiculata, S. caseolaris, S. alba dan A. alba (Tabel 3). Rhizophora maupun Sonneratia merupakan kelompok mangrove sejati yang tumbuh di zona yang dipengaruhi oleh pasang surut air laut serta toleran terhadap kadar salinitas yang lebih tinggi (Wang et al., 2011), kemudian Avicennia merupakan spesies yang memiliki rumpun daun yang lebat serta helaian daun yang tipis (Saru et al., 2017) dan merupakan salah satu jenis mangrove yang mensekresi garam laut di daunnya (Hamzah \& Setiawan, 2010), sedangkan $X$. granatum merupakan jenis mangrove yang berukuran sedang, kulit batang tipis dan mengelupas (Saheb et al., 2015) serta tumbuh di wilayah yang jauh dari genangan air pasang laut (lebih dekat dengan daratan) (Mughofar et al., 2018). Selain itu, Tabel 3 juga memperlihatkan bahwa komposisi jenis vegetasi mangrove di kawasan penginisiasian KKPD Rupat Utara tertingginya berada di Pulau Babi, dimana komposisi jenisnya lebih rendah bila dibandingkan dengan pulau kecil lainnya di Indonesia, baik itu di Pulau Harimau (Kamal \& Haris, 2014), Sempu (Sulistiyowati, 2009), Mantehage (Schaduw et al., 2011), Dompak (Lestari, 2013) maupun Tanakeke (Setiawan \& Mursidin, 2018), sedangkan dengan Pulau Larat (Pulumahuny, 2003), Seira (Pulumahuny, 2003), Wotab (Pulumahuny, 2003), Wuliaru (Pulumahuny, 2003), Kore (Pulumahuny, 2003), Taming (Kamal \& Haris, 2014), Panjang (Kamal \& Haris, 2014), Tunda (Syahrial et al., 2017; Syahrial \& Novita, 2018; Syahrial \& Sastriawan, 2018), Nain (Schaduw, 2018), Miangas (Syahrial et al., 2018a,b) dan Maitara (Riyadi \& Sarni, 2018), komposisi jenis vegetasi mangrove Pulau Babi lebih tinggi.

Tabel 7. Tingkat kerawanan degradasi mangrove pada kawasan penginisiasian KKPD Rupat Utara

\begin{tabular}{|c|c|c|c|c|c|c|}
\hline St & $\begin{array}{c}\text { Kerapatan Pohon } \\
\text { (ind/ha) }\end{array}$ & $\begin{array}{c}\text { Tingkat } \\
\text { Kerentanan } \\
\text { Degradasi }\end{array}$ & $\begin{array}{c}\text { Kerapatan } \\
\text { Anakan } \\
\text { (ind/ha) }\end{array}$ & $\begin{array}{c}\text { Tingkat } \\
\text { Kerentanan } \\
\text { Degradasi }\end{array}$ & $\begin{array}{c}\text { Kerapatan } \\
\text { Semai } \\
\text { (ind/ha) }\end{array}$ & $\begin{array}{c}\text { Tingkat } \\
\text { Kerentanan } \\
\text { Degradasi } \\
\end{array}$ \\
\hline 1 & $\begin{array}{c}1833 \\
\pm 496.10\end{array}$ & $\begin{array}{l}\text { Kerentanan } \\
\text { Rendah }\end{array}$ & $\begin{array}{c}2800 \\
\pm 873.48\end{array}$ & $\begin{array}{l}\text { Kerentanan } \\
\text { Rendah }\end{array}$ & $\begin{array}{c}50000 \\
\pm 17638.34\end{array}$ & $\begin{array}{l}\text { Kerentanan } \\
\text { Rendah }\end{array}$ \\
\hline 2 & $\begin{array}{c}1750 \\
\pm 401.04\end{array}$ & $\begin{array}{l}\text { Kerentanan } \\
\text { Rendah }\end{array}$ & $\begin{array}{c}1400 \\
\pm 707.11\end{array}$ & $\begin{array}{l}\text { Kerentanan } \\
\text { Sedang }\end{array}$ & $\begin{array}{l}10000 \\
\pm 0.00\end{array}$ & $\begin{array}{l}\text { Kerentanan } \\
\text { Rendah }\end{array}$ \\
\hline 3 & $\begin{array}{c}775 \\
\pm 134.82\end{array}$ & $\begin{array}{l}\text { Kerentanan } \\
\text { Sedang }\end{array}$ & $\begin{array}{c}150 \\
\pm 35.36\end{array}$ & $\begin{array}{l}\text { Kerentanan } \\
\text { Tinggi }\end{array}$ & $\begin{array}{c}13750 \\
\pm 3145.76\end{array}$ & $\begin{array}{l}\text { Kerentanan } \\
\text { Rendah }\end{array}$ \\
\hline 4 & $\begin{aligned} & 2525 \\
\pm & 638.15\end{aligned}$ & $\begin{array}{l}\text { Kerentanan } \\
\text { Rendah }\end{array}$ & $\begin{array}{c}1250 \\
\pm 309.23\end{array}$ & $\begin{array}{l}\text { Kerentanan } \\
\text { Sedang }\end{array}$ & $\begin{array}{c}15000 \\
\pm 3061.86\end{array}$ & $\begin{array}{l}\text { Kerentanan } \\
\text { Rendah }\end{array}$ \\
\hline 5 & $\begin{array}{c}1544 \\
\pm 1013.52\end{array}$ & $\begin{array}{l}\text { Kerentanan } \\
\text { Rendah }\end{array}$ & $\begin{array}{c}844 \\
\pm 168.26\end{array}$ & $\begin{array}{l}\text { Kerentanan } \\
\text { Sedang }\end{array}$ & $\begin{array}{c}20000 \\
\pm 12570.79\end{array}$ & $\begin{array}{l}\text { Kerentanan } \\
\text { Rendah }\end{array}$ \\
\hline 6 & $\begin{array}{r}1400 \\
+332.78 \\
\end{array}$ & $\begin{array}{l}\text { Kerentanan } \\
\text { Sedang }\end{array}$ & $\begin{array}{c}1067 \\
\pm 203.67 \\
\end{array}$ & $\begin{array}{l}\text { Kerentanan } \\
\text { Sedang }\end{array}$ & $\begin{array}{c}6667 \\
\pm 0.00 \\
\end{array}$ & $\begin{array}{c}\text { Kerentanan } \\
\text { Rendah }\end{array}$ \\
\hline
\end{tabular}

Berdasarkan pengamatan dan pengukuran di lapangan, keanekaragaman hayati mangrove di kawasan penginisiasian KKPD Rupat Utara masih tergolong rendah, pemusatan jenis mangrove di suatu area (dominansi) tidak terjadi, mangrovenya memiliki daya adaptasi yang tinggi (tidak membentuk kelompok) serta komunitas mangrovenya tersebar merata (distribusi stabil) (Tabel 4), sehingga mengindikasikan bahwa setiap individu mangrove di kawasan penginisiasian KKPD Rupat Utara tidak berkompetisi dalam memenuhi kebutuhan hidupnya (memanfaatkan secara bersama-sama), dimana terjadinya kompetisi di suatu ekosistem, umumnya dipicu oleh perebutan kebutuhan hidup, baik itu cahaya matahari, ruang tumbuh maupun unsur hara (Nurhamiyawan et al., 2013). Lovelock et al., (2004) menyatakan bahwa unsur hara yang dibutuhkan mangrove untuk pertumbuhan adalah nitrogen dan fosfor, sedangkan untuk pertumbuhan tinggi dan diameter batangnya, mangrove sangat bergantung pada ruang tumbuh, permukaan tajuk, kelembaban nisbi, sistem perakaran, pengaruh iklim dan kesuburan tanah (Syah et al., 2012). Menurut McGuinness (1997) faktor-faktor yang mempengaruhi penyebaran dan pertumbuhan mangrove adalah pengeringan akibat pasang surut air laut, gangguan, pemangsaan serta persaingan, dimana persaingan suatu tanaman sangat bergantung pada kecepatan tumbuh perakaran, sedangkan kecepatan tumbuh perakaran bergantung pada kemampuan fotosintesis (Indriyanto, 2008). Selain itu, karakteristik substrat (Budiasih et al., 2015), pengendapan (sedimentasi) (Purnobasuki, 2011), campur tangan manusia (Smith et al., 2003), ketinggian rata-rata permukaan laut (Purnobasuki, 2011), kondisi fisika kimia perairan (Hamzah \& Pancawati, 2013) dan pencemaran perairan (Purnobasuki, 2011) juga dapat mempengaruhi pertumbuhan mangrove.

Salah satu spesies mangrove yang tumbuh dan berkembang baik di kawasan penginisiasian KKPD Rupat Utara adalah $X$. granatum (jumlah keseluruhannya 225 ind) (Tabel 5). Hal ini terlihat dari nilai INP yang diperolehnya sangat tinggi, baik itu kategori pohon (191.74\%) maupun semai $(240.80 \%)$. Di Indonesia, X. granatum tumbuh di Jawa, Madura, Bali, Kepulauan Karimun Jawa, Sumatera, Sulawesi, Kalimantan, Maluku, Sumba dan Irian Jaya (Noor et 
al., 2006), kemudian $X$. granatum juga ditemukan di sekitar pesisir Samudera Hindia tropis (Mulholland \& Taylor, 1992), sedangkan di Malaysia, Kerala dan Tamilnadu, $X$. granatum sudah tergolong langka dan akan punah (Haron \& Taha, 2010). Selanjutnya di Maharashtra dan Pantai Barat India, X. granatum ditemukan kembali setelah 9 dekade dan dikategorikan sebagai tumbuhan yang terancam punah (Jugale et al., 2009) dan pengamatan terbaru mengungkapkan bahwa $X$. granatum sama sekali tidak ditemukan lagi di hutan mangrove Godavari India (Saheb et al., 2015).

Kondisi kesehatan mangrove di kawasan penginisiasian KKPD Rupat Utara, pada bagian daratan utamanya semakin terancam oleh pengrusakan dibandingkan dengan pulau kecil yang ada di sekitarnya (Tabel 6), walaupun secara keseluruhan tingkat kerawanan degradasi mangrove di kawasan penginisiasian KKPD Rupat Utara masih sangat rendah (Tabel 7). Pengrusakan pohon induk (kategori pohon) dan peremajaan (kategori anakan) banyak terjadi di Desa Suka Damai dengan dugaan pengrusakan adalah aktivitas manusia (antropogenik), baik itu untuk pembukaan lahan perkebunan kelapa sawit, karet maupun permukiman penduduk. Hal ini merupakan dampak dari peningkatan populasi manusia di wilayah pesisir (Kulkarni et al., 2010; Yan \& Xu 2010; Ward et al., 2011; UNEP 2014). Marfai et al., (2008) menyatakan bahwa degradasi lingkungan di wilayah pesisir biasanya banyak terjadi di daerah yang memiliki kepadatan penduduk yang tinggi. Selain itu, juga karena kedekatannya dengan pusat-pusat kota, industri, peternakan akuatik (akuakultur) ataupun pelabuhan (Prasad, 2012; Zhang et al., 2014).

Di Sri Lanka misalnya salah satu faktor utama yang mengancam ekosistem mangrovenya adalah budidaya udang, sehingga menyebabkan peningkatan erosi pantai dan penurunan produksi perikanan pantai dari tahun 1992 - 2009 (Harkes et al., 2015), kemudian di pantai Selatan Cina, ekologi ekosistem mangrovenya mengalami stres serius dan menyebabkan $66 \%$ hutan mangrovenya hilang akibat dari urbanisasi dan industrialisasi yang cepat ( $\mathrm{Li} \&$ Lee, 1997). Selanjutnya di Douala yang merupakan kota besar Kamerun, telah memberikan tekanan besar terhadap hutan mangrove di sekitarnya dengan pembuangan limbah yang tidak terkendali, sehingga mempengaruhi keseluruhan ekosistem mangrovenya (Simon \& Raffaelli, 2012). Sementara itu, pengurangan luasan mangrove akibat dari aktivitas manusia (antropogenik) juga terjadi di beberapa negara seperti Kenya (Aboudha \& Kairo, 2001), Puerto Rico (Martinuzzi et al., 2009), Cina (Yan \& Xu, 2010; Chen \& Ye, 2011), Australia (Eslami-Andargoli et al., 2010), Malaysia (Kamali \& Hashim, 2011), Madagaskar (Rakotomavo \& Fromard, 2010), Afrika Barat (Giri et al., 2011; Friess \& Webb, 2013), Myanmar (Giri et al., 2008), Brazil (Magris \& Barreto, 2010), Vietnam (Hishamunda et al., 2009), Australia (ABS, 2002), India (Kulkarni et al., 2010), Senegal (Diop et al., 1997), Teluk Arab (Al-Khayat et al., 2019), Bangladesh (Giri et al., 2008), Florida (Lewis, 1976), Thailand (Giri et al., 2008), Filipina (Hishamunda et al., 2009) dan Indonesia (Kusmana, 2011; Ilman et al., 2016; Zainuri et al., 2017; Baderan, 2017).

\section{SIMPULAN}

Jenis mangrove di kawasan penginisiasian KKPD Rupat Utara ditemukan sebanyak 12 spesies, dimana keanekaragaman dan dominansi mangrovenya tergolong rendah, sedangkan kemerataan atau penyebarannya tergolong stabil. Selain itu, kondisi penutupan mangrove kategori pohon terbaiknya berada di Stasiun 4, sedangkan kategori anakan dan semainya di Stasiun 1. X. granatum merupakan spesies dominan untuk kategori pohon dan semai, sedangkan A. alba merupakan spesies dominan untuk kategori anakan, dimana kondisi kesehatan mangrove di kawasan penginisiasian KKPD Rupat Utara secara keseluruhannya masih tergolong baik (sangat padat) dan tingkat kerawanan degradasi mangrovenya tergolong rendah.

\section{UCAPAN TERIMA KASIH}

Ucapan terima kasih disampaikan kepada Balai Pengelolaan Sumber Daya Pesisir dan Laut (BPSPL) Padang yang telah memfasilitasi penulis dalam melakukan penelitian ini. Selanjutnya ucapan terima kasih juga disampaikan kepada UPTD Perikanan Rupat Utara dan BMC Universitas Riau, sehingga terselesainya penelitian ini dengan lancar.

\section{DAFTAR PUSTAKA}

Aboudha, P. A. W., \& Kairo, J. G. (2001). Humaninduced stresses on mangrove swamps along the Kenyan coast. Hydrobiologia. 458(1-3): $255-265$. DOI:

http://dx.doi.org/10.1023/A:1013130916811.

[ABS] Australian Bureau of Statistics. (2002). Year Book Australia 2002. Canberra, Australia. 893 p.

Al-Khayat, J. A., Abdulla, M. A., \& Alatalo, J. M. (2019). Diversity of benthic macrofauna and physical parameters of sediments in natural mangroves and in afforested mangroves three decades after compensatory planting. Aquatic Sciences. 81(4): 1 - 11. DOI: http://dx.doi.org/10.1007/s00027-018-0599-7.

Alongi, D. M. (2018). Impact of global change on nutrient dynamics in mangrove forests. Forests. 9(10): 1 - 13. DOI: http://dx.doi.org/10.3390/f9100596.

Angulo, V. J. A., \& Hatcher, B. G. (2010). A new typology of benefits derived from marine protected areas. Marine Policy. 34: 635 - 644. DOI: http://dx.doi.org/ 10.1016/j.marpol.2009.12.002.

Baderan, D. W.K. (2017). Distribusi spasial dan luas kerusakan hutan mangrove di wilayah pesisir Kwandang Kabupaten Gorontalo Utara Provinsi Gorontalo. GeoEco. 3(1): $1-8$.

Bayen, S. (2012). Occurrence, bioavailability and toxic effects of trace metals and organic contaminants in 
mangrove ecosystems: A review. Environment International. 48: 84 - 101. DOI: http://dx.doi.org/10.1016/j.envint.2012.07.008.

Bengen, D. G. (2004). Pedoman Teknis Pengenalan dan Pengelolaan Ekosistem Mangrove. Pusat Kajian Sumberdaya Pesisir dan Lautan, IPB. Bogor, Indonesia.

Bosire, J. O., Dahdouh-Guebas, F., Walton, M., Crona, B. I., Lewis III, R. R., Field, C., Kairo, J. G., \& Koedam, N. (2008). Functionality of restored mangroves: A review. Aquatic Botany. 89(2): 251 259. DOI: http://dx.doi.org/10.1016/j.aquabot.2008.03.010.

[BPS] Badan Pusat Statistik Kabupaten Bengkalis. (2016). Kecamatan Rupat Utara Dalam Angka 2016. Bengkalis, Indonesia. 77 hal.

[BPS] Badan Pusat Statistik Kabupaten Bengkalis. (2017). Kecamatan Rupat Utara Dalam Angka 2017. Bengkalis, Indonesia. 66 hal.

Brown, B. (2007). Resilience Thinking Applied to the Mangroves of Indonesia. IUCN \& Mangrove Action Project. Yogyakarta, Indonesia. 53 p.

Budiasih, R., Supriharyono, \& Muskananfola, M. R. (2015). Analisis kandungan bahan organik, nitrat, fosfat pada sedimen di kawasan mangrove jenis Rhizophora dan Avicennia di Desa Timbulsloko, Demak. Management of Aquatic Resources. 4(3): 66 75.

Chakraborty, S. K. (2013). Interactions of environmental variables determining the biodiversity of coastal-mangrove ecosystem of West Bengal, India. The Ecoscan. 3(Special): 251 - 265.

Chen, G. C., \& Ye, Y. (2011). Restoration of Aegiceras corniculatum mangroves in Jiulongjiang Estuary changed macro-benthic faunal community. Ecological Engineering. 37(2): 224 - 228. DOI: http://dx.doi.org/10.1016/j.ecoleng.2010.10.003.

Diop, E. S., Soumare, A., Diallo, N., \& Guisse, A. (1997). Recent changes of the mangroves of the Saloum River Estuary, Senegal. Mangroves and Salt Marshes. 1(3): 163 - 172. DOI: http://dx.doi.org/10.1023/A:1009900724172.

Eslami-Andargoli, L., Dale, P. E. R., Sipe, N., \& Chaseling, J. (2010). Local and landscape effects on spatial patterns of mangrove forest during wetter and drier periods: Moreton Bay, Southeast Queensland, Australia. Estuarine, Coastal and Shelf Science. 89(1): 53 - 61. DOI: http://dx.doi.org/10.1016/j.ecss.2010.05.011.

Feller, I. C., Lovelock, C. E., Berger, U., McKee, K. L., Joye, S. B., \& Ball, M. C. (2010). Biocomplexity in mangrove ecosystems. Annual Review of Marine Science. 2: 395 - 417. DOI:

http://dx.doi.org/10.1146/annurev.marine.010908 .163809 .

Friess, D. A., \& Webb, E. L. (2013). Variability in mangrove change estimates and implications for the assessment of ecosystem service provision. Global Ecology and Biogeography. 23(7): 715 - 725. DOI: http://dx.doi.org/10.1111/geb.12140.
Gaut, B. S. (2018). A convergent outcome: Small genomes in mangroves. New Phytologist. 217(1): 5 7. DOI: http://dx.doi.org/10.1111/nph.14906.

Giri, C., Zhu, Z., Tieszen, L. L., Singh, A., Gillette, S., \& Kelmelis, J. A. (2008). Mangrove forest distributions and dynamics $(1975$ - 2005) of the tsunami-affected region of Asia. Biogeography. 35(3): 519 - 528. DOI: http://dx.doi.org/10.1111/j.13652699.2007.01806.x.

Giri, C., Ochieng, E., Tieszen, L. L., Zhu, A., Singh, A., Loveland, T., Masek, J., \& Duke, N. (2011). Status and distribution of mangrove forests of the world using earth observation satellite data. Global Ecology and Biogeography. 20(1): 154 - 159. DOI: http://dx.doi.org/10.1111/j.14668238.2010.00584. $\mathrm{x}$.

Hamilton, S. (2013). Assessing the role of commercial aquaculture in displacing mangrove forest. Bulletin of Marine Science. 89(2): 585 - 601. DOI: http://dx.doi.org/10.5343/bms.2012.1069.

Hamilton, S. E., \& Casey, D. (2016). Creation of a high spatio-temporal resolution global database of continuous mangrove forest cover for the $21^{\text {st }}$ century (CGMFC-21). Global Ecology and Biogeography. 25(6): 729 - 738. DOI: http://dx.doi.org/10.1111/geb.12449.

Hamzah, F., \& Pancawati, Y. (2013). Fitoremidiasi logam berat dengan menggunakan mangrove. Ilmu Kelautan. 18(4): 203 - 212. DOI: http://dx.doi.org/10.14710/ik.ijms.

Hamzah, F., \& Setiawan, A. (2010). Akumulasi logam berat $\mathrm{Pb}, \mathrm{Cu}$, dan $\mathrm{Zn}$ di hutan mangrove Muara Angke, Jakarta Utara. Ilmu dan Teknologi Kelautan Tropis. 2(2): $41-52$.

Harkes, I. H. T., Drengstig, A., Kumara, M. P., Jayasinghe, J. M. P. K., \& Huxham, M. (2015). Shrimp aquaculture as a vehicle for climate compatible development in Sri Lanka: The case of Puttalam Lagoon. Marine Policy. 61: 273 - 283. DOI:

http://dx.doi.org/10.1016/j.marpol.2015.08.003.

Haron, N. W., \& Taha, R. M. (2010). Taxonomy, distribution and propagation of Xylocarpus species at Carey Island - The Heritage Island of Malaysia. Proceedings $2^{\text {nd }}$ International Conference on Landscape and Urban Hort. 9 - 13 Juni 2009. Bologna, Italy. $997-1004$.

Hartati, \& Harudu, L. (2016). Identifikasi jenis-jenis kerusakan ekosistem hutan mangrove akibat aktivitas manusia di Kelurahan Lowulowu Kecamatan Lea-Lea Kota Baubau. Penelitian Pendidikan Geografi. 1(1): 30 - 45.

Hishamunda, N., Ridler, N. B., Bueno, P., \& Yap, W. G. (2009). Commercial aquaculture in Southeast Asia: Some policy lessons. Food Policy. 34(1): $102-$ 107. DOI:

http://dx.doi.org/10.1016/j.foodpol.2008.06.006.

Holguin, G., Vazquez, P., \& Bashan, Y. (2001). The role of sediment microorganisms in the productivity, conservation, and rehabilitation of mangrove ecosystems: An overview. Biology and 
Fertility of Soils. 33(4): 265 - 278. DOI: http://dx.doi.org/10.1007/s003740000319.

Ilman, M., Dargusch, P., Dart, P., \& Onrizal. (2016). A historical analysis of the drivers of loss and degradation of Indonesia's mangroves. Land Use Policy. 54: $448 \quad-\quad 459 . \quad$ DOI: http://dx.doi.org/10.1016/j.landusepol.2016.03.01 0 .

Indriyanto. (2008). Ekologi Hutan. Bumi Aksara. Jakarta, Indonesia. 210 hal.

Ishak, \& Saputra, I. A. (2015). Pengaruh aktivitas penduduk terhadap kerusakan hutan mangrove di Desa Lalombi Kecamatan Banawa Selatan. GeoTadulako. 3(6): $52-63$.

Jin-Eong, O. (1995). The ecology of mangrove conservation \& management. Hydrobiologia. 295(13): 343 - 351. DOI: http://dx.doi.org/10.1007/BF00029141.

Jugale, S., Bhosale, L. J., Kad, T. D., \& Nadaf, A. B. (2009). Genetic diversity assessment in intra- and inter-populations of Xylocarpus granatum Koen.: A critically endangered and narrowly distributed species of Maharashtra. Current Science. 97(5): 695 701.

Kamal, E., \& Haris, H. (2014). Komposisi dan vegetasi hutan mangrove di pulau-pulau kecil di Pasaman Barat. Ilmu Kelautan. 19(2): 113 - 120. DOI: http://dx.doi.org/ 10.14710/ik.ijms.19.2.113-120.

Kamali, B., \& Hashim, R. (2011). Mangrove restoration without planting. Ecological Engineering. 37(2): $387 \quad$ - $391 . \quad$ DOI: http://dx.doi.org/10.1016/j.ecoleng.2010.11.025.

Kaunang, T. D., \& Kimbal, J. D. (2009). Komposisi dan struktur vegetasi hutan mangrove di Taman Nasional Bunaken Sulawesi Utara. Agritek. 17(6): $1163-1171$.

Kuenzer, C., Bluemel, A., Gebhardt, S., Quoc, T. V., $\&$ Dech, S. (2011). Remote sensing of mangrove ecosystems: A review. Remote Sensing. 3(5): 878 928. DOI: http://dx.doi.org/10.3390/rs3050878.

Kulkarni, V. A., Jagtap, T. G., Mhalsekar, N. M., \& Naik, A. N. (2010). Biological and environmental characteristics of mangrove habitats from Manori Creek, West Coast, India. Environmental Monitoring and Assessment. 168(1-4): 587 - 596. DOI: http://dx.doi.org/10.1007/s10661-009-1136-x.

Kusmana, C. (2011). Management of mangrove ecosystem in Indonesia. Pengelolaan Sumberdaya Alam dan Lingkungan. 1(2): 152 - 157. DOI: http://dx.doi.org/10.29244/jpsl.1.2.152.

Lestari, F. (2013). Identifikasi kondisi ekosistem mangrove di kawasan pesisir Pulau Dompak Tanjungpinang. Agriplus. 23(2): $92-97$.

Lewis, R. R. (1976). Impacts of dredging in the Tampa Bay Estuary, 1876 - 1976. Proceedings of The Second Annual Conference of The Coastal Society. 1976 November 17 - 20. New Orleans, Louisiana. 31 $55 \mathrm{p}$.

Li, M. S., \& Lee, S. Y. (1997). Mangroves of China: A brief review. Forest Ecology and Management. 96(3): 241 - 259. DOI: http://dx.doi.org/10.1016/S03781127(97)00054-6.
Lovelock, C. E., Feller, I. C., McKee, K. L., Engelbrecht, B. M. J., \& Ball, M. C. (2004). The effect of nutrient enrichment on growth, photosynthesis and hydraulic conductance of dwarf mangroves in Panama. Functional Ecology. 18(1): 25 - 33. DOI: http://dx.doi.org/10.1046/j.02698463.2004.00805.x.

Macnae, W. (1968). A general account of the fauna and flora of mangrove swamps and forests in The Indo-West-Pacific region. Advances in Marine Biology. 6: 73 - 270. DOI:

http://dx.doi.org/10.1016/S0065-2881(08)604381.

Magris, R. A., \& Barreto, R. (2010). Mapping and assessment of protection of mangrove habitats in Brazil. Pan-American Journal of Aquatic Sciences. 5(4): $546-556$.

Marfai, M. A., Almohammad, H., Dey, S., Susanto, B., \& King, L. (2008). Coastal dynamic and shoreline mapping: Multi-sources spatial data analysis in Semarang Indonesia. Environmental Monitoring and Assessment. 142(1-3): 297 - 308. DOI: http://dx.doi.org/10.1007/s10661-007-9929-2.

Martinuzzi, S., Gould, W. A., Lugo, A. E., \& Medina, E. (2009). Conversion and recovery of Puerto Rican mangroves: 200 years of change. Forest Ecology and Management. 257(1): 75 - 84. DOI:

http://dx.doi.org/10.1016/j.foreco.2008.08.037.

Mastaller, M. (1997). Mangrove: The Forgotten Forest Between Land and Sea. Kuala Lumpur, Malaysia.

Mayaux, P., Holmgren, P., Achard, F., Eva, H., Stibig, H., \& Branthomme, A. (2005). Tropical forest cover change in the 1990s and options for future monitoring. Philosophical Transactions of The Royal Society B Biological Sciences. 360(1454): 373 384. DOI: http://dx.doi.org/10.1098/rstb.2004.1590.

McGuinness, K. A. (1997). Seed predation in a tropical mangrove forest: A test of the dominancepredation model in northern Australia. Tropical Ecology. 3(2): 293 - 302. DOI: http://dx.doi.org/10.1017/S0266467400010464.

[MNLH] Menteri Negara Lingkungan Hidup. (2004). Keputusan Menteri Negara Lingkungan Hidup Tentang Kriteria Baku dan Pedoman Penentuan Kerusakan Mangrove No. 201. Jakarta, Indonesia.

Mughofar, A., Masykuri, M., \& Setyono, P. (2018). Zonasi dan komposisi vegetasi hutan mangrove Pantai Cengkrong Desa Karanggandu Kabupaten Trenggalek Provinsi Jawa Timur. Pengelolaan Sumberdaya Alam dan Lingkungan. 8( 1): 77 - 85. DOI: http://dx.doi.org/ 10.29244/jps1.8.1.77-85.

Mulholland, D. A., \& Taylor, D. A. H. (1992). Limonoids from Australian members of the Meliaceae. Phytochemistry. 31(12): 4163 - 4166. DOI: http://dx.doi.org/10.1016/00319422(92)80434-G.

Noor, Y. R., Khazali, M., \& Suryadiputra, I. N. N. (2006). Panduan Pengenalan Mangrove di Indonesia. Bogor, Indonesia. 227 hal.

Nurhamiyawan, E. N. L., Prihandono, B., \& Helmi. (2013). Analisis dinamika model kompetisi dua 
populasi yang hidup besama di titik kesetimbangan tidak terdefinisi. Buletin Ilmiah Matematika, Statistika dan Terapan. 2(3): $197-204$.

Onrizal. (2010). Perubahan tutupan hutan mangrove di pantai Timur Sumatera Utara periode 1977-2006. Biologi Indonesia. 6(2): 163 - 172. DOI: http://dx.doi.org/10.14203/jbi.v6i2.3154.

Osland, M., Feher, L., Griffith, K., Cavanaugh, K., Enwright, N., Day, R. H., Stagg, C. L., Krauss, K. W., Howard, R. J., Grace, J. B., \& Rogers, K. (2016). Climatic controls on the global distribution, abundance and species richness of mangrove forests. Ecological Monographs. 87(2): 341 - 359. DOI: http://dx.doi.org/10.1002/ecm.1248.

Polania, J., Urrego, L. E., \& Agudelo, C. M. (2015). Recent advances in understanding Colombian mangroves. Acta Oecologica. 63: 82 - 90. DOI: http://dx.doi.org/10.1016/j.actao.2015.01.001.

Prasad, M. B. K. (2012). Nutrient stoichiometry and eutrophication in Indian mangroves. Environmental Earth Sciences. 67(1): 293 - 299. DOI: http://dx.doi.org/10.1007/s12665-011-1508-8.

Pulumahuny, F. S. (2003). Hutan mangrove di pulaupulau kecil Kepulauan Yamdena Maluku Tenggara. Pesisir dan Pantai Indonesia. 8: 33 - 42.

Purnobasuki, H. (2011). Ancaman terhadap hutan mangrove di Indonesia dan langkah strategis pencegahannya. Bulletin PSL Universitas Surabaya. 25: $3-6$.

Rakotomavo, A., \& Fromard, F. (2010). Dynamics of mangrove forests in the Mangoky River delta, Madagascar, under the influence of natural and human factors. Forest Ecology and Management. 259(6): $1161 \quad-\quad 1169 . \quad$ DOI: http://dx.doi.org/10.1016/j.foreco.2010.01.002.

Richards, D. R., \& Friess, D. A. (2016). Rates and drivers of mangrove deforestation in Southeast Asia, 2000-2012. Proceedings of The National Academy of Sciences. 113(2): 344 - 349. DOI: http://dx.doi.org/10.1073/pnas.1510272113.

Riyadi, S., \& Sarni. (2018). Kapasitas adaptif mangrove pada pulau kecil mikro studi di Pulau Maitara Kota Tidore Kepulauan Propinsi Maluku Utara. Biologi Tropis. 18(2): 123 - 133. DOI: http://dx.doi.org/ 10.29303/jbt.v18i2.801.

Saheb, S. K. B., Kishore, I. V., Babu, K., Rosaiah, G., \& Mallikarjuna, K. (2015). Diversity of seed germination in Xylocarpus species. International Journal of Pharma and Bio Sciences. 6(2): B846 B854.

Salm, R. V., Clark, J. R., \& Siirila, E. 2010. Marine and Coastal Protected Areas: A Guide for Planners and Managemnet. Gland, Swisterland. 396 p.

Sandilyan, S., \& Kathiresan, K. 2012. Mangrove conservation: A global perspective. Biodiversity and Conservation. 21(14): 3523 - 3542. DOI: http://dx.doi.org/10.1007/s10531-012-0388-x.

Saru, A., Amri, K., \& Mardi. (2017). Konektivitas struktur vegetasi mangrove dengan keasaman dan bahan organik total pada sedimen di Kecamatan Wonomulyo Kabupaten Polewali Mandar. Spermonde. 3(1): $1-6$.
Schaduw, J. N. W. (2018). Struktur komunitas dan keberlanjutan pengelolaan ekosistem mangrove pulau-pulau kecil (Kasus pada Pulau Nain Kabupaten Minahasa Utara Provinsi Sulawesi Utara). Ilmu Lingkungan. 16(2): 120 - 129. DOI: http://dx.doi.org/ 10.14710/jil.16.2.120-129.

Schaduw, J. N. W., Yulianda, F., Bengen, D. G., \& Setyobudiandi, I. (2011). Pengelolaan ekosistem mangrove pulau-pulau kecil Taman Nasional Bunaken berbasis kerentanan. Agrisains. 12(3): 173 $-181$.

Setiawan, H., \& Mursidin. (2018). Karakteristik ekologi dan kesehatan hutan mangrove di Pulau Tanakeke Sulawesi Selatan. Penelitian Kehutanan Wallacea. 7(1): 47 - 58 .

Setyobudiandi, I., Sulistiono, Yulianda, F., Kusmana, C., Hariyadi, S., Damar, A., Sembiring, A., \& Bahtiar. (2009). Sampling dan Analisis Data Perikanan dan Kelautan: Terapan Metode Pengambilan Contoh di Wilayah Pesisir dan Laut. Fakultas Perikanan dan Ilmu Kelautan, Institut Pertanian Bogor. Bogor, Indonesia.

Simon, L. N., \& Raffaelli, D. (2012). Assessing ecosystem effects of small-scale cutting of Cameroon mangrove forests. Ecology and the Natural Environment. 4(5): 126 - 134. DOI: http://dx.doi.org/10.5897/JENE11.131.

Smith, K. A., Ball, T., Conen, F., Dobbie, K. E., Massheder, J., \& Rey, A. (2003). Exchange of greenhouse gases between soil and atmosphere: Interactions of soil physical factors and biological processes. European Journal of Soil Science. 54(4): 779 - 791. DOI: http://dx.doi.org/10.1046/j.13510754.2003.0567.x.

Sulistiyowati, H. (2009). Biodiversitas mangrove di Cagar Alam Pulau Sempu. Sainstek. 8(1): 59-63.

Syah, C., Indrawan, A., \& Priyono, A. (2012). Pertumbuhan Rhizophora mucronata pada lahan restorasi mangrove di Hutan Lindung Angke Kapuk, Jakarta. Bonorowo Wetlands. 2(1): $1-10$. DOI: http://dx.doi.org/10.13057/wetlands/w020101.

Syahrial, \& Novita, M. Z. (2018). Inventarisasi mangrove dan gastropoda di Pulau Tunda Serang Banten, Indonesia serta distribusi spasial dan konektivitasnya. Saintek Perikanan. 13(2): 94 - 99. DOI: http://dx.doi.org/ 10.14710/ijfst.13.2.94-99.

Syahrial, \& Sastriawan, Y. (2018). Pola sebaran, indikator kualitas lingkungan dan ekologi komunitas mangrove Pulau Tunda. Saintek Perikanan. 14(1): 43 - 50. DOI: http://dx.doi.org/ 10.14710/ijfst.14.1.43-51.

Syahrial, Lubis, K. M., Pranata, E., Hamdani, R., Syahrian, W., Purnama, D. P., Kaprisal, \& Hutasuhut, M. D. (2017). Variasi geografik kerapatan mangrove dan kepadatan gastropoda serta keterkaitannya di Pulau Tunda Serang Banten, Indonesia. Biowallacea. 4(2): 591 - 601. DOI:http://dx.doi.org/10.33772/biowallacea.v4i2. 4232. 
Syahrial, Karsim, N., \& Lubis, K. M. (2018a). Keanekaragaman hayati mangrove sejati di Pulau Miangas. Maspari. 10(2): 207 - 216. DOI: http://dx.doi.org/ 10.36706/maspari.v10i2.5954.

Syahrial, Syahrian, W., \& Heriyanto, T. (2018b). Inventarisasi dan pola penyebaran regenerasi alami semai mangrove sejati di Utara Indonesia. Perikanan dan Kelautan. 23(1): 39 - 46. DOI: http://dx.doi.org/ 10.31258/jpk.23.1.39-46.

Thomas, N., Lucas, R., Bunting, P., Hardy, A., Rosenqvist, A., \& Simard, M. (2017). Distribution and drivers of global mangrove forest change, 1996 - 2010. Plos One. 12(6): 1 - 14. DOI: http://dx.doi.org/10.1371/journal.pone.0179302.

[UNEP] The United Nations Environment Programme. (2014). The Importance of Mangroves to People: A Call to Action. Cambridge, England. 128 p.

Valenca, A. P. M. C., \& Santos, P. J. P. (2012). Macrobenthic community for assessment of estuarine health in tropical areas(Northeast, Brazil): Review of macrofauna classification in ecological groups and application of AZTI Marine Biotic Index. Marine Pollution Bulletin. 64(9): 1809 - 1820. DOI:

http://dx.doi.org/10.1016/j.marpolbul.2012.06.00 3.

Vane, C. H., Harrison, I., Kim, A. W., Moss-Hayes, V., Vickers, B. P., \& Hong, K. (2009). Organic and metal contaminantion in surface mangrove sediments of South China. Marine Pollution Bulletin. 58(1): 134 - 144. DOI: 10.1016/j.marpolbul.2008.09.024.

Wang, L., Mu, M., Li, X., Lin, P., \& Wang, W. (2011). Differentiation between true mangroves and mangrove associates based on leaf traits and salt contents. Plant Ecology. 4(4): 292 - 301. DOI: http://dx.doi.org/10.1093/jpe/rtq008.

Wang, Y., Qiu, Q., Xin, G., Yang, Z., Zheng, J., Ye, Z., \& Li, S. (2013). Heavy metal contamination in a vulnerable mangrove swamp in South China. Environmental Monitoring and Assessment. 185(7): 5775 - 5787. DOI:

http://dx.doi.org/10.1007/s10661-012-2983-4.
Ward, P. J., Marfai, M. A., Yulianto, F., Hizbaron, D. R., \& Aerts, J. C. J. H. (2011). Coastal inundation and damage exposure estimation: A case study for Jakarta. Natural Hazards. 56(3): 899 - 916. DOI: http://dx.doi.org/10.1007/s11069-010-9599-1.

Wiryawan, B., \& Dermawan, A. (2006). Panduan Pengembagan Kawasan Konservasi Laut Daerah (Marine Management Area/MMA) di Wilayah Coremap II - Indonesia Bagian Barat. Editor: Suraji. Coral Reef Rehabilitation and Management Program II - Direktorat Jenderal Kelautan, Pesisir dan Pulau-Pulau Kecil Departemen Kelautan dan Perikanan. Jakarta, Indonesia. 96 hal.

Woodroffe,C. D., \& Grindrod, J. (1991). Mangrove biogeograhy: The role of quaternary environmental and sea-level change. Biogeography. 18(5): 479 492. DOI: http://dx.doi.org/10.1017/S0266467400002431.

Yan, L., \& Xu, X. (2010). Assessing the vulnerability of social - Environmental system from the perspective of hazard, sensitivity and resilience: A case study of Beijing, China. Environmental Earth Sciences. 61(6): 1179-1186. DOI: http://dx.doi.org/10.1007/s12665-009-0440-7.

Zainuri, A.M., Takwanto, A., \& Syarifuddin, A. (2017). Konservasi ekologi hutan mangrove di kecamatan mayangan Kota Probolinggo. Dedikasi. 14: $1-7$.

Zhang, Z., Xu, X., Sun, Y., Yu, S., Chen, Y., \& Peng, J. (2014). Heavy metal and organic contaminants in mangrove ecosystems of China: A review. Environmental Science and Pollution Research. 21(20): 11938 - 11950. DOI: http://dx.doi.org/10.1007/s11356-014-3100-8. 